\title{
Chinese Migration and Settlement in Austria
}

\author{
Kim Kwok
}

\begin{abstract}
Chinese migration to Austria displays some characteristics of the new Chinese migration order facilitated by, among other factors, globalisation and the open-door policies of the People's Republic of China. This paper offers a historical account of Chinese migration to Austria against a broader background of Chinese migration to Europe, illustrating both the active and the passive roles of Austria in various historical periods. Moreover, through delineating and analysing the distribution by subgroups and the characteristics of the Chinese community in Austria since the 1980s, it elaborates how Austria has shifted from being a temporary transit point to becoming home for the new non-qiáoxiāng Chinese migrants.
\end{abstract}

Keywords: Chinese in Austria, new Chinese migration order, migration history, Chinese community enna Journal of East Asian Studies, Volume 4, eds. Rudiger Frank, Ina Hein, Lukas Pokorny and Agnes Schick-Chen. Vienna: Praesens Verlag, 2013, pp. 27-49. 


\section{Introduction}

As a small central European country situated at the geographical heart of Europe, Austria has played different roles in various historical periods within the context of Chinese migration to Europe. ${ }^{1}$ The aim of this paper is twofold. Firstly, it examines the history and processes of Chinese migration to Austria against a broader background of Chinese migration trends in Europe. Secondly, it illustrates how Austria has evolved from being a temporary place of transit to becoming a permanent home for new non-qiáoxiāng ${ }^{2}$ 侨 Chinese migrants since the 1980s. This paper will begin with a general overview of the studies on Chinese migration to Europe and will then set off on a historical journey back to the beginning of the 20th century. This will be followed by an exploration of developments in the Chinese community in the postWorld War II period. Finally, an overview of the socio-demographic profile of Chinese migrants in Austria since the 1980s will be provided.

\section{Chinese migration in Europe}

Despite increasing media and policy attention towards Chinese migration to Europe, no one can offer a reliable number of Chinese migrants residing in Europe. Documented nationals from the People's Republic of China (PRC) were recorded at about 580,000 in 2009, the second largest non-EU foreign group residing in the European Union member states (which at that time numbered 27). Those from Taiwan numbered around 8,000 (Eurostat 2012). Sources that include those who have become European citizens or are born in Europe put the estimated number of ethnic Chinese in Europe at around 2 million, or even 2.5 million (Zhuāng 2011; Lĭ Mínghuān 2009).

Compared to the studies on Chinese migration in Southeast Asia and in America, Chinese migration to Europe has been a relatively new topic in academia, both in Europe and in China. Starting almost from scratch roughly 20 years ago, scholarly research has by now yielded a reasonably reliable picture of some basic facts and

An earlier Chinese version of this paper-Àodili huárén de yímín lìshǐ hé shèqún fēnbù 奥地利华人的移民 历史和社群分布 [Migration History and Community Mapping of Chinese in Austria]—was published in Huáqiáo huárén lishí yánjīu 华侨华人历史研究 [Overseas Chinese History Studies], 4, 2012, pp. 31-40.

1 'Chinese migration' within Europe is used in this paper as a general term denoting migration of all ethnic Chinese including those who are born in Europe, naturalised European passport-holders, old Chinese migrants who came to Europe prior to 1978 and new Chinese migrants who arrived after 1978. The term 'New Chinese migrants' denote all Chinese from Mainland China, Taiwan, Hong Kong and Macao, with those from Mainland China being the dominant group.

2 The term non-qiáoxiāng incorporates a combination of qiáo 侨 (sojourner) and xiāng 乡 (homeland), meaning the home villages or places from where Chinese migrants originally left with the ultimate intention of returning one day. It is more applicable to people with a strong sense of loyalty and a primordial sentiment towards their homeland in China. 
outlines of Chinese migration in Europe. The Chinese in Europe (1998), edited by Gregor Benton and Frank Pieke, is the first work in English to discuss the Chinese in different European countries. It provides useful and solid information about Chinese migration in terms of migration origin, migration trajectories, statistical summaries and socio-economic activities. Following The Chinese in Europe, monographs, journal articles and unpublished theses emerged one after another in the first decade of the new millennium, filling up many lacunae in the overall picture of Chinese migration to Europe.

In general, studies on Chinese migration to Europe can be classified into two types of work. The first comprises studies on Chinese migrants in individual countries, such as Pál Nyíri's New Chinese Migrants in Europe: The Case of the Chinese Community in Hungary (1999), Maggi Leung's Chinese Migration in Germany: Making Home in Transnational Space (2004), and Gregor Benton and Edmund Terence Gomez's The Chinese in Britain, 1800-Present: Economy,Transnationalism, Identity (2008). The second type focuses on such special themes as Chinese transnationalism, Chinatown and the Chinese religious community in Europe. Examples are Frank Pieke et al.'s Transnational Chinese: Fujianese Migrants in Europe (2004), Flemming Christiansen's Chinatown, Europe: An Exploration of Overseas Chinese Identity in the 1990s (2003), and Dorottya Nagy's Migration and Theology: The Case of Chinese Christian Communities in Hungary and Romania in the Globalisation Context (2009). In China, publications on Chinese migration to Europe started with the pioneer scholar Lì Mínghuān's 李明欢 report The Chinese Community in Europe (1999a) and her History of Overseas Chinese in Europe 欧洲华侨华人史 ${ }^{3}$ (2002). Lǐ and other scholars such as Sòng Quánchéng 宋全成 and Wáng Yìhóng 王 异虹 have continuously contributed to the discussions on Chinese migration in Europe in Chinese academic circles.

In the past 30 years, migration among Chinese people has increased in volume and diversified in pattern to a degree never seen before, building up to what Frank Pieke (2007) calls the 'new Chinese migration order'. Resulting from the interaction of several factors including globalisation and the economics of Western higher education, this new order is characterised by the commercialisation of emigration from China, a diversification of destination, and a proliferation of student and professional migration, marking the moment when China became a crucial hub in global migration. The 'new Chinese migration order' as it unfolded in Europe in the new millennium emerges from a summing-up of the discussions and observations from Frank Pieke (2007), Lǐ Mínghuān (2009) and Sòng Quánchéng (2011) with the following features and trends: firstly, the rising number of Chinese migrants, which makes Europe the region with the fastest growing Chinese population in the world. The second feature is the diversity in terms of geographical origins and social- 
economic backgrounds of Chinese migrants. While qiáoxiāng migrants from Zhèjiāng 浙江, Fújiàn 福建 and Guăngdōng 广东 provinces constitute the majority of the Chinese population in Europe, the group of non-qiáoxiāng elite migrants, including skilled labour and students originating from different Chinese urban areas, is expanding. Thirdly, with the development of Chinese catering, IT business, trading and tourism in Europe, the social and economic status of the Chinese population in general has improved. Fourthly, a certain number of irregular Chinese migrants are still struggling at the bottom level of the Chinese community. Their social and economic status remains vulnerable. The last noticeable trend is that more and more Chinese in Europe exhibit transnational life patterns.

Located at the geographical heart of the European continent, Austria lies between the new (Eastern and Southern Europe) and old (Western Europe) destinations of Chinese migration. ${ }^{4}$ Together with Belgium, Germany, Switzerland and the Nordic countries, Austria was named as one of the countries on the 'semi-periphery' for Chinese migration (Pieke 2002). This was because these countries were not the most popular destinations for the non-qiáoxiāng Chinese migrants at the beginning of the reform and open-door era. Notwithstanding this, Austria's significant geographical position made it a common transit corridor for various flows of Chinese migrants. With time, and particularly in the context of the 'new Chinese migration order', Chinese migrants have gradually made Austria a home in which to settle and a final destination of migration. The aforementioned characteristics of the 'new Chinese migration order' can, moreover, also be identified in the Austrian Chinese community.

However, none of the above-listed literature has covered Chinese migrants in Austria. To my knowledge, up to now literature on the Chinese in Austria has been almost exclusively in German. Information available in English or Chinese is rare. In Austria, while there are some publications about the Chinese community and organisations (Kreissl 1999; Khan-Svik 2003; Waldrauch and Sohler 2004; Gebesmair 2009), more studies have appeared in the form of master's theses (e.g. Springer 2004; Vuong 2007; Steiger 2008; Wang 2008; Hausner 2009; Schäfer 2009; Mosleh 2012). However, none of them has provided a comprehensive historical account of Chinese migration to Austria. The present paper therefore attempts to bridge this research gap. My analyses are based on historical documentation, memoirs and statistical data as well as on first-hand fieldwork material collected for my doctoral dissertation in the period 2005-09 and 2011.

4 According to Frank Pieke (2002), Chinese migration in Europe since the 1980s can be roughly classified into three blocks: Western Europe, Southern Europe and Eastern Europe. Western Europe consists of the old destinations of Chinese migration such as the Netherlands, France and Britain. Southern Europe includes Italy, Spain and Greece, whereas Eastern Europe includes Hungary, the Czech Republic, the former Yugoslavia (particularly Serbia) and Romania. The latter two blocks are new destinations for Chinese migrants. 


\section{Early Chinese sojourners in Austria prior to World War II}

Historical links between China and Europe go back several centuries, yet it was not until the late 19th century and the early 20th century that the Chinese presence in Europe became apparent. To a certain extent this was facilitated by factors such as religious, maritime and semi-colonial connections between some of the European powers and China. Two major migratory flows from China can be distinguished at this earlier time: contract labourers and traders. While around 100,000 Chinese contract labourers were recruited during World War I for building roads, graves and trenches in France (Summerskill 1982), others played an important role in opening up Russia's Far East before the 1917 Revolution (Larin 1998). Moreover, Cantonese seamen working for European shipping companies settled in some major port cities such as London, Liverpool, Rotterdam and Hamburg (Pieke 2002).

The Chinese arrival in Austria was part of the second flow: traders and street peddlers, and refers to the advent of Chinese from Qīngtián 青田, a mountainous and economically deprived region in the hinterland of the port city of Wēnzhōu 温州 in Zhèjiāng province. In order to sustain a livelihood, Qīngtián people undertook stone carving of pale-green soapstone ${ }^{5}$ as a sideline occupation besides farming. The story goes that a man called Chēn Yuánfēng 陈元丰 should be considered the pioneer. He went to Europe by steamer in 1893 and later found out that stone carving had a high economic value in Europe (Thunø 1999). While most of the labourers recruited during World War I were Chinese from the northern province of Shāndōng 山东, about 2,000 men were from Qīngtián. After the war almost all of the Shāndōng Chinese returned to China. Nearly half of the Qīngtián labourers stayed behind in Europe and brought their families and relatives over. The 1920s and 1930s became a high period of emigration from Qingtián to Europe, with the estimated number of Qīngtián Chinese spreading across continental Europe as high as 25,000. They earned their living by trading and street peddling of Chinese handicrafts such as porcelain, stone carving, silk and glass (Thunø 1999). Documentary records show that there was a Qīngtián trading community in the vicinity of the Lyon train station in Paris (Lǐ Mínghuān 1999b), and some silk products were believed to have been produced by Chinese migrants in Milan (Cologna 2005).

An anecdotal story of the late 18 th century suggests that the first Chinese to appear in Austria were two Chinese travelling as servants on a ship. It was thought that they arrived in Trieste on 8 February 1780 on board the Kaunitz, a ship of the Austrian East Indian Company, and then came to Vienna. One of these two Chinese appears to have spent ten years as a weaver in the province of Salzburg, before he settled down in Nußdorf/Attersee around 1790. He is said to have married into a

5 Stone carving from pale-green soapstone has become a local folk art in Qīngtián. The special soapstone from the region of Qīngtián has been named Qīngtián stone (qīngtiánshil青田石). 
farming family and taken his wife's family name because his own name was hard to pronounce for the people in the village (Kreissl 1999).

On a tiny scale, real Chinese settlement started with Qīngtián traders at the turn of the 20th century in a similar fashion to what was happening in other parts of Europe. Evidence of early Chinese street peddlers in Vienna and the surrounding areas was provided by the conservative Christian Socialist newspaper the Reichspost from the Austro-Hungarian empire before World War I. At that time, Chinese were the targets of racial hostility, which was widespread in the Western world and linked to the 'yellow peril' discourse. An article titled 'Chinese Invasion of Vienna' was published by the Reichspost on 19 February 1913 (John and Lichtblau 1990: 61):

\begin{abstract}
Recently, there appear to be a conspicuous number of lower class Chinese in Vienna and its vicinity. ...In their greasy Chinese costumes or shady European clothes, they cross the streets and gather an audience at some favourite places, such as in front of the ice-skating square, where they bring out from their wide bags or baskets all kinds of fans, knickknacks and statuettes. ... In this way they not only violate the law on hawking and the tax regulations, but also certainly harm the customers. It is time for the authorities to put an end to these things. ${ }^{6}$
\end{abstract}

At the end, twenty-four Chinese men are said to have been deported from Vienna in 1914 (Lǐ Yáng 1991a). After the outbreak of World War I, many Chinese returned to China. Later in the 1930s, there appeared to be a small Chinese community in the area of Breitensee, where they sold Chinese curios in the local wine taverns and gathered sometimes in a café for mahjong (májiàng 麻将) playing (Li Yáng 1991b; John and Lichtblau 1990). It is estimated that about 1,000 Qīngtián Chinese settled in Austria during the period of the 1920s-1930s (Thunø 1999).

Besides street peddlers, there were students who came to Austria particularly in the form of student exchanges between the two world wars. Their choice of profession was mostly a practical one, intended to be of immediate use to China, such as medicine, law, technology and German. Many of these students were simultaneously engaged in social and political activities with the aim of helping to correct the relatively distorted image of China in Austria in the 1920s and 1930s (Kaminski and Unterrieder 1980; Lǐ Yáng 1992a).

A vivid account of the common migratory experiences of Qīngtián people and the interactions between them and the Chinese students in the 1930s was offered by a student, Yú Shūpíng 俞叔平, in his later years (Yú 1993):

We had a Chinese Student Association in Vienna at that time. Because of the dreadful attitude of the employees at the Chinese Embassy, we planned to take radical action in order to help them [the Qīngtián street peddlers] to vent their anger. ...Those deprived Qīngtián

6 The translation from the original German text is my own. In this paper, all translations from Chinese and German are mine unless specified otherwise. 
people were really pitiful. Because of the poor farming conditions and natural disasters in Qingtián, they were forced to leave with neither passport nor money for travel. Most of them got out by sneaking into the laundry on foreign commercial ships. Usually when they went ashore in Italy or France, they would be caught by the local police to be deported. Since the travel expenses for sending them back home were large, they were sent from one European country to another. The Qingtián people took this opportunity to travel around. Being a fellow Zhèjiāngnese, I translated for them in court. Actually their Qīngtián dialect was much more difficult to understand than German; I just tried my best to say something nice for them.

In March 1938, Austria was annexed by Nazi Germany. During the Nazi era, the sole wish of all the Chinese living in German-speaking areas was to go home. Some managed to do so successfully, while some did not. Although there was no specific record of discriminatory policies targeting the Chinese, like many other foreigners they were not able to escape the harassment and hostility aimed at alien racial elements (fremdrassische Elemente) (Yú 1993). Among the dozens of Chinese leftists, it is believed that some were accused by the Gestapo of being intelligence agents for the enemy and were put into concentration camps (Lǐ Yáng 1992b). The history of Chinese migration to Austria was interrupted abruptly with the outbreak of World War II.

\section{Venturing into the catering business in the post-World War II period}

Amid the post-war economic hardships in bombed-out Vienna, some of the few Chinese who were left were able to re-establish themselves. Two Chinese restaurants were opened in Vienna shortly after World War II, one of which was reported in a local newspaper, Wiener Tageszeitung, on 29 July 1948 (John and Lichtblau 1990: 61-62): ${ }^{8}$

7 当时我们在维也纳有个中国留奥同学会, 为了使馆人员的恶劣态度, 想采取激烈手段, 替他们出气。 $(\cdots)$ 那些穷苦的青田人, 说来非常可怜, 因青田地癒民贫, 自然的灾难, 逼着他们向外跑, 既无护 照, 又无旅费, 十之八九, 都是混在外国商船的洗衣工作里出去的。在意大利或法国上岸, 就被当 地的警察抓住, 驱逐出境, 因为遣送回国, 耗费甚大, 只好在国与国之间送来送去, 他们也趁着这 个机会周游列国。因为是浙江老乡, 我替他们在法院里当通译, 实际上他们的青田话, 比德文还难 懂, 只好替他们说句好话就是了。Dāngshí wǒmén zài wéiyěnà yǒu gè zhōngguǒ liúào tóngxuéhuì, wèile shřguăn rényuán de èliè tàidù, xiăng cáiqŭ jíliè shǒuduàn, tì tāmén chūqì.(...) nàxiē qióngkǔ de qīngtiánrén, shuōlái fēicháng kělián, yīn qīngtián dìjímínpín, jìrán de zāimàn, bìzhuō tāmén xiàngwàibăo, jì wú hùzhào, yòu wú lŭfèi, shízhībājiǔ, dōushì hùn zài wàiguó shāngchuán de xǐyī gōngzuò lǐi chūqù de. Zài yìdàlì huò făguó shàng'àn, jiu bèi dāngdì de jǐngchá zhuāzhù, qūzhúchùjìng, yīnwei qiănsònghuíguó, hàofèi shèndà, zhíhăo zài guó yǔ guó zhījiān sòngláisòngqù, tāmén yě chènzhuó zhègè jīhuì zhōuyóu lièguó. Yīnwei shì Zhèjiāng lăoxiāng, wǒ tì tāmén zài făyuàn lǐ dāng tōngyì, shíjìshāng tāmén de qīngtiánhuà, bì déwén hái nándǒng, zhíhăo tì tāmén shuō jù hăohuà jiùshì le.

8 The title of the article in the Wiener Tageszeitung of 29 July 1948 is 'Middle Kingdom in Rudolfsheim: The Unromantic Life of the Chinese Colony' ('Reich der Mitte in Rudolfsheim. Das unromantische Leben der chinesischen Kolonie'). 
The Shanghai Restaurant of the respectable Mr Yeh Jen-Tchen, located in a small house at the Meidlinger Hauptstrasse, is equipped with clean, freshly-arranged chairs and tables with linoleum table-cloths. It is not much different from the other ordinary taverns in the Meidlinger area or from the completely European interior of the second Chinese restaurant on the Neubaugürtel in Vienna. ...At present the Chinese in Vienna have difficulty in obtaining food that suits their taste. The primary problem is the lack of rice. Both of the Chinese restaurants, at which nearly all the members of the Chinese colony ${ }^{9}$ receive their meals, are on short rations....

This first record of Chinese restaurants in Austria dating from 1948 marked the beginning of a new era in Chinese migrant ventures in Austria: decades of initiatives in the catering business which continue up to the present. Nobody could predict at that early time that the opening of Chinese restaurants would since become the main survival strategy of Chinese in Austria. However, the sour atmosphere of the 1950s did not promise immediate success. Throughout the 1950s and the 1960s, business and life were still very hard and featured a period of muddling through for survival. The number of Chinese restaurants as well as the number of Chinese migrants remained small. Besides catering, many of the Chinese earned their living by working as construction workers at that time (Wiener Tageszeitung, 29 July 1948, cited in John and Lichtblau 1990). Professor Xú Zhīxiù 徐芝秀, who later became a lecturer in Chinese language at the University of Vienna, came to Vienna in the 1950s and worked in one of the Chinese restaurants. In an interview in 1995, she suggested that the poor business that Chinese restaurants did was due to the low income of the general public at that time. Instead, the Chinese restaurant became a place of gathering for the few Chinese living in Vienna (Xiăo 1995).

In the post-World War II period, Europe witnessed two major flows of Chinese migration. The first was the large-scale, economically motivated migration from Hong Kong (Xiānggăng 香港), and on a smaller scale from Malaysia and Singapore, to Britain. Responding to the demand in the booming catering industries in Western Europe, these people later moved on to other European countries such as Belgium, the Netherlands, Germany and Scandinavia. Secondly, political turmoil and economic instability in the newly founded independent nation-states in Southeast Asia prompted an influx of ethnic Chinese from Vietnam, Cambodia, Laos and Indonesia, who arrived in France and the Netherlands in the 1960s and 1970s, drawing on colonial links (Pieke 2002).

Having no such links in Asia such as the old core colonial powers in Europe had had, Austria experienced neither the influx of Asian refugees during the political turmoil in Southeast Asia in the 1960s and 1970s, nor the arrival of working migrants in large numbers from Hong Kong, Malaysia and Singapore. Nevertheless,

9 The 'Chinese colony' is the original term used in the German text and presumably refers to the Chinese community in general, yet the implication of using the term is unclear. 
small numbers of Chinese were allowed to leave the PRC in the 1970s, enabling some Zhèjiāngnese migrants from Qīngtián to come to Austria to join the Taiwanese in the catering business. Taiwanese migrants formed the first settler group in the post-World War II era in Austria. Among them, the very first pioneers were a number of retired soldiers of Shāndōng origin, who went to Taiwan after 1949 with the Guómíndăng 国民党 government and chose Europe as their next stage in life in the 1950s or the 1960s. They arrived in Austria with acquired cooking skills and capital, either directly from Taiwan or through another country such as Germany. With a positive response from Austrian customers, these pioneers were followed by family and friends in the next decades, until they gradually lost their market share in the catering business to the Zhèjiāngnese from the 1980s onwards. Well-known names among these Taiwanese of Shāndōng origin are Qí Jǐngshān 齐景山 and Wú Jiācái 吴家财. Today, some of their descendants are still active in the catering business in Austria.

The growth of the Chinese community and Chinese restaurants started gradually in the 1970s. Three Chinese restaurants are thought to have existed at the end of the 1960s in Vienna, all of them owned by Taiwanese. Ten years later, by the end of the 1970 s, there were already about 60 Chinese restaurants, of which more than one half were owned by Taiwanese. ${ }^{10}$ Kaminski and Unterrieder (1980) estimate that there were about 1,000 Chinese living in Vienna at the end of the 1970s, of whom around two-thirds were nationals of the Republic of China (ROC-Taiwan). The size of the Chinese community at that time was comparable to that in the period of the $1920 \mathrm{~s}-$ 1930 s.

\section{Developments in the Chinese community from 1980 onwards}

Starting from the 1980s, the Chinese community in Austria has undergone substantial changes. There was a remarkable increase in numbers and diversification of the socio-economic profile, reflecting global Chinese migration trends, and in particular the flows and patterns to Europe. According to the official data, the Chinese population in Austria has demonstrated a steady increase since the influx of new migrants

10 The three Chinese restaurants in the 1960s would have been the Beijing Restaurant in the 1st district, Jinlong Restaurant in the Porzellangasse, and the China Pavilion in the Schönbrunn area, all in Vienna. The Jinlong Restaurant (or the Goldener Drachen), run by Wú Jiācái’s 吴家财 family, is still in existence. See http://www.goldener-drachen.at/. 
in the 1980s. ${ }^{11}$ A drastic leap happened between 1981 and 1991, from 800 to 3,537, which meant that the number more than quadrupled within ten years. From 2001 to 2011, despite facing more restrictive immigration regulations, the Chinese population doubled. Presently Austria accommodates 10,153 people who are PRC or ROC (Taiwan) passport holders. Of these, Vienna records 6,121, more than half of the total Chinese population (Table 1). In the last three decades, around 8,000 former passport-holders of the PRC and of the ROC (Taiwan) have been naturalised to become Austrian citizens. ${ }^{12}$ This suggests that this group of people with Chinese backgrounds have usually been subsumed under the category 'Austria' in the statistics. Putting these two figures together, we come to a total of 18,153 people with ethnic Chinese backgrounds in Austria. However, these figures by no means reflect the accurate size of this group. For instance, there is neither a record of those naturalised Chinese who have already left Austria or who have passed away, nor documentation of the second- and third-generation Chinese who are born with Austrian nationality. Moreover, the number of ethnic Chinese holding Indian, Cambodian, Vietnamese or Singaporean passports is unknown. Apart from all these statistical limitations, the number of Chinese whose status in Austria is irregular - the so-called Dunkelziffer (dark figure), as the Austrian media usually put it—remains as a 'mysterious' question mark. The figures of asylum seekers can at best give us a very slight hint of the picture (Table 2). Generally, it is estimated that there are 20,000-25,000 ethnic Chinese residing in Austria, 12,000-15,000 of them in Vienna, including the abovementioned group of irregular migrants. Nevertheless, it should be emphasised that the figures presented here are estimates rather than accurate statistics.

Table 1 Documented Chinese in Austria, 1961-2010 (PRC and Taiwan)

\begin{tabular}{|c|r|r|r|r|r|c|}
\hline Year & $\mathbf{1 9 6 1}$ & $\mathbf{1 9 7 1}$ & $\mathbf{1 9 8 1}$ & $\mathbf{1 9 9 1}$ & $\mathbf{2 0 0 1}$ & $\mathbf{2 0 1 1}$ \\
\hline Austria & 18 & 73 & 800 & 3537 & 4567 & 10,153 \\
\hline Vienna & 16 & 53 & 510 & 1770 & 2660 & 6121 \\
\hline
\end{tabular}

Source: Statistisches Zentralamt, Volkszählung 1961, 1971, 1981, 1991; Statistik Austria, Volkszählung 2001, Statistisches Jahrbuch Österreich 2012.

11 It is worth noting that the Austrian authorities do not have a consistent policy in treating the statistical data of people with PRC nationality and those with Taiwan nationality. Before 2001, Taiwanese passportholders were often classified as Chinese from the PRC and were not listed separately, a lack of clarity or confusion that still exists today. Moreover, as registered Chinese migrants constitute merely a tiny percentage of the total foreign population in Austria and Vienna, they are not specified in most of the official statistics, but are rather buried under the heading of 'Asians' or 'others'.

12 Source of information: Statistik Austria, Statistisches Jahrbuch Österreich 2002, 2005, 2012; Stadt Wien, Statistisches Jahrbuch der Stadt Wien, 2012. 
Table 2 Chinese asylum seekers in Austria, 1980-2010 (PRC and Taiwan)

\begin{tabular}{|c|c|c|c|c|}
\hline & PR China & $\begin{array}{l}\text { Successful asylum } \\
\text { in numbers }\end{array}$ & Taiwan & $\begin{array}{l}\text { Successful asy- } \\
\text { lum in numbers }\end{array}$ \\
\hline 1980-89 & 55 & --- & & \\
\hline 1990-99 & 272 & --- & & \\
\hline 2000 & 53 & --- & 37 & --- \\
\hline 2001 & 95 & --- & 59 & --- \\
\hline 2002 & 666 & 0 & 113 & 0 \\
\hline 2003 & 573 & 6 & 88 & 4 \\
\hline 2004 & 571 & 4 & 92 & 1 \\
\hline 2005 & 468 & 0 & 24 & 0 \\
\hline 2006 & 194 & 25 & 18 & 0 \\
\hline 2007 & 209 & 35 & 14 & 0 \\
\hline 2008 & 223 & 18 & 13 & 1 \\
\hline 2009 & 368 & 38 & 30 & 10 \\
\hline 2010 & 200 & 29 & 17 & 3 \\
\hline Total & 3947 & 155 & 505 & 19 \\
\hline
\end{tabular}

Source: Bundesministerium für Inneres, Asylwesen Jahresstatistiken 1999-2010.

Migration from China to Europe in the open-door and reform era has been marked by the revitalisation of pre-1949 migration networks of Zhèjiāngnese and Fújiànese. Refreshing their former networks of kinship and friends, Zhèjiāng Chinese from Qīngtián and the neighbouring areas of Wēnzhoū 温州, Wénchéng 文成and Lìshuǐ 丽水, the traditional qiāoxiāng, have migrated in large numbers in a classic chain 
migration pattern since the $1980 \mathrm{~s} .{ }^{13}$ Many of them first touched down in places where they had relatives and friends, and later moved around in Europe beyond their traditional destinations in search of business and job opportunities regardless of the then national borders. It is therefore not surprising that the Chinese have been dubbed 'Europeans before the Europeans' (Benton and Pieke 1998: viii). Around the same time, forerunners from the Fúzhoū 福州 and Fúqīng 福清 qiāoxiāng areas in Fújiàn province also found their way to Europe and joined the cohort of Zhèjiāngnese en route through either regular or irregular migration channels, though in more modest numbers.

Figure 1 Zhèjiāng and Fújiàn provinces: places of origin of Chinese migrants

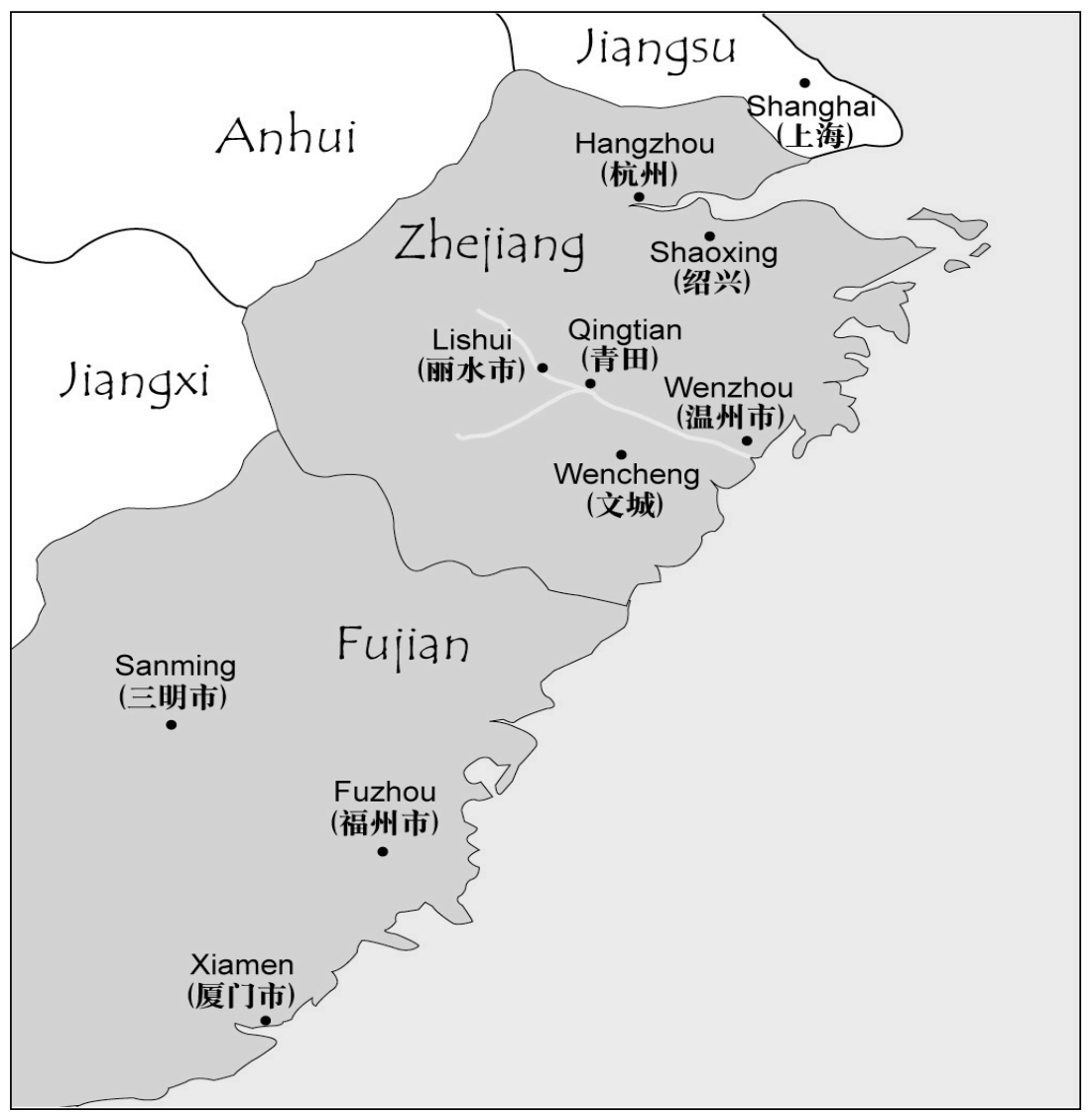

13 Qīngtián is now a county included in the administration of the prefectural-level city of Lìshuǐ. In China, a prefectural-level city is not only a city, but an administrative unit containing a major urban area and its larger surrounding area including many smaller cities, towns and villages. 
Similarly to some other European countries such as Italy, Germany and France, the Chinese population in Austria has been dominated by Zhèjiāngnese, especially those from Qingtián area. While there are no official data, it is generally believed in the Chinese community in Austria that Zhèjiāng Chinese make up 70-80 percent of the total Chinese population; among them again 70-80 percent are Qīngtián Chinese. The rapid chain migration of Zhèjiāng people in the early reform era can be manifested in the Austrian official statistics for the 1980s and 1990s as noted above. The Zhèjiāngnese first came to work for Taiwanese restaurant owners in Austria, and later they gradually took over the business from the Taiwanese and developed it in their own way. Most of the Zhèjiāng Chinese work in the catering business today, either as employees or as restaurant owners. The second business niche in which they are engaged is the wholesale as well as retail business of groceries, textiles, toys and decorative items. The chain migration of Zhèjiāngnese has continued until recently. It is not uncommon to find Qingtiánese families with more than one hundred family members spreading all through Austria today.

Other than Chinese coming from the traditional qiāoxiāng areas in Zhèjiāng and working in the catering business, are there other groups of Chinese migrants in Austria? To answer this question, the following sections will examine the different Chinese subgroups on the basis of either their place of origin or their occupational background. Chinese coming from Taiwan, the first group who laid the foundations of the Chinese catering business in Austria, have remained stagnant in number, if they are not already decreasing. Besides the arrival of the Zhèjiāngnese, economic growth in Taiwan in the 1980s and the 1990s, which made work migration to Europe less attractive, can also partly explain the decline in the Taiwanese catering business. Consequently many Taiwanese left Austria, either returning to Taiwan or joining the 'China fever' to try their fortune in mainland China. However, they usually do not retreat entirely from Austria, as many still keep their Austrian residence, citizenship and networks, travelling back and forth between Asia and Europe for employment and business opportunities and thus featuring a kind of transnational settlement. Their second generation are usually well-educated young Taiwanese with a wide spectrum of professional backgrounds. Their motivation for earning their living in the catering business as their parents did remains low. A distinctive occupational group among the Taiwanese is the high-end information technology industry, which had its heyday in the 1990s but has subsided since 2000. Tourism remains an appealing field among the Taiwanese, an area where competition with the mainland Chinese has become fierce. It is estimated that there are around 2,000 people with Taiwanese backgrounds living in Austria. ${ }^{14}$

14 Information obtained from an interview with the former chairman of a Taiwanese voluntary association, Chinesischer Verein in Österreich, in 2005. 
As mentioned, Austria did not experience a direct influx of Asian refugees during the political turmoil in Southeast Asia in the 1960s and 1970s. Nevertheless, the granting of political asylum in the late 1970s and early 1980s led to the arrival of around 2,000 Vietnamese and Cambodian refugees in Austria (Stanek 1985: 155167), the majority of whom were ethnic Chinese of Cantonese origin. Upon arrival, most of them were allocated to areas around the industrial city of Linz, where lowskilled jobs in factories were available. Without a single connection to this new country prior to their arrival, these ethnic Chinese from Vietnam and Cambodia had to start from scratch. Many of them had not even heard of the country Austria before it was introduced to them by officers of the United Nations High Commissioner for Refugees in their place of safe haven, which was Hong Kong, Thailand or Singapore. As people granted refugee status, they were offered intensive assistance right at the beginning of their stay to establish a modest life in Austria. ${ }^{15}$ Over the years, many have moved to other urban places such as Vienna and Salzburg to look for new jobs, as Austria has been undergoing structural changes to its industry since the 1990 s and many manufacturing industries have closed down. Unlike the Zhèjiāngnese, this group of Chinese from Indochina and their second generation are obviously less active as entrepreneurs. With few exceptions, most of them make their living as wage-earners. ${ }^{16}$ According to Mr Zēng 曽, the founder of the then Indochina Chinese Refugee Mutual Aid Association 旅奥中南半岛华裔难友互助 会 $^{17}$, the comparatively better protection offered by the social system might be the reason for the lack of motivation in being self-employed. The assistance and support forthcoming from the Austrian authorities and the access they have to most of the welfare entitlements enabled them to enter the circle of 'insiders' in the Austrian welfare system upon their arrival.

Adopting the classical guest-worker concept, Austria commenced recruiting foreign nurses and channelled them into the health sector of the labour market, which faced a labour shortage from the 1970s. Following the examples of nurses from the Philippines and from Kerala in India (Hintermann and Reeger 2005), a group of Chinese nurses from Qīngdăo 青岛, Shànghăi 上海 and Běijīng 北京, whose total number did not exceed 400, came to Austria in the period 1991-1996 as contract nurses to work in the hospitals of Vienna. Their recruitment was carried out through bilateral contracts between the city of Vienna and the cities of Shànghăi, Qīngdăo

15 A Patenschaftsprogramm (godparent programme) subsidised by the Austrian Ministry of Interior Affairs was organised by Caritas especially for this group of refugees from Indochina at the beginning of the 1980s. A local family was assigned voluntarily to each newly arrived refugee family with the aim of assising them to integrate better into the new environment, especially in areas like accommodation, jobs, medical care, German courses and children's education. For details see Stanek 1985.

16 One well-known example among the exceptions are the two Saigon restaurants in Vienna, which are run by second-generation Vietnamese with ethnic Chinese background; see http://saigon.markgraf.at/.

17 Lüào zhōngnán bàndăo huáyì nànyoǔ hùzhùhuì 
and Běijīng respectively for a period of two years. Most of these nurses, especially those from Qīngdăo, stayed behind after their two years' contract had expired; some of them returned to China but came back to Austria after realising the still-existing differences in wages and working conditions. Today nearly all of them are still working in the health sector, forming one of the most integrated groups of Chinese migrants in the local labour market. They have brought their husbands and families for family reunification, gradually enlarging their small sub-community. Although Chinese nurses form only a very marginal group in terms of numbers within the Chinese community, they demonstrate a spectacular trajectory of female migration as independent skilled labour with a leading role in the family, and not as family dependents. $^{18}$

At the lowest rung of the social ladder are the new migrants without legal status. Very much alike to the situation in some other European countries, this irregular group is composed largely of Chinese from Fújiàn province and Dōngběi 东北 (northeast China, which includes the three provinces of Hēilóngjiāng 黑龙江, Jílín 吉林 and Liáoníng 辽宁). Once the heavy manufacturing base of China's centrally planned economy, Dōngběi was the first to be left behind as other parts of the country moved toward a market economy in the earlier reform era. Many of the factories and mines of China's 'rust belt' have closed, causing rising numbers of laid-off workers, especially from state-owned enterprises. Although people from Dōngběi have been active in Europe for more than a decade, the size of the group is difficult to estimate (Paul 2002). Researchers suggest that emigration from Dōngběi has been driven by emigration companies operating in full view of the authorities and are connected to state-owned enterprises in China (Paul 2002; Xiang 2007). Since the new millennium, Austria has been witnessing the arrival of Dōngběi Chinese of different age and social groups, ranging from young students to laid-off workers in their fifties. Dōngběi Chinese usually head directly to Austria with a short-term tourist or business visa and stay behind after the expiration of their visa, while Fújiàn Chinese enter Austria mostly 'illegally', with the help of professional human traffickers. Fújiànese from the Sānmíng 三明 area, an internal part of Fújiàn province and a nascent member in the emigration market (Pieke 2002; Lǐ Mínghuān et al. 2003), have already been touching base in Austria since the early 1990s. In contrast, their fellow migrants from the Fúzhoū 福州 region, a traditional coastal qiáoxiāng area in Fújiàn province, have only begun to appear in the Chinese community in Austria on a much smaller scale since 2000. Unlike the Zhèjiāngnese, Fújiàn and Dōngběi Chinese migrate to Austria without any connection to prior networks.

18 Information obtained from first-hand field work. Traditionally, female migration from developing to developed countries is characterised by women's dependent status, as they are the ones who follow their husbands. To a large extent, this phenomenon has been reflected in the Chinese qiáoxiāng migration to Austria. Chinese nurses' migration to Austria, however, unfolds an opposite pattern. 
As many of the Dōngběi and Fújiàn Chinese first arrived in Austria through irregular channels, they have tried to secure their stay in Austria by applying for asylum, which grants them the temporary right to reside in the country but no right to travel in and out. Some of them have managed to obtain legal status and access to the regular labour market, while others still remain socially and legally vulnerable. Those possessing no legal resident status and no kin support are usually driven into the informal sector of the Chinese economy: unfavourable casual jobs such as kitchen help, child care, manual work and even prostitution behind closed doors. Generally speaking, these two groups of people have not only found personal shelter at the lower end of the hierarchy of the Chinese economy in Austria, but have also provided convenient and cheap labour for it to survive with greater vigour. It is evident that the vital development of the Chinese economy depends to a certain extent on the exploitation of cheap co-ethnic Chinese labour. For example, one Fújiànese informant revealed that his wage was one-third less than his colleagues'. He possesses no legal residence and no work permit and has worked as a cook in a Chinese restaurant for years.

Another eye-catching new migrant group is formed by young educated Chinese, composed mostly of students who have come to Austria since 2000 in a wave of student migration. Facilitated by favourable conditions such as the rising income of urban Chinese middle-class families and policies of student migration, studying abroad has become the driving force and best way of pursuing qualifications and experiences overseas (Xiang and Shen 2009). As a spillover from the flow of Chinese students to the most common destinations in Europe-Britain, France and Germany-Austria received Chinese students and scholars to a modest extent in the 1990s. Since 2000, through the migration networks of study agents, the arrival of Chinese students has surged. According to the Federal Ministry of Science and Research, the number of registered students from the PRC in all public universities in Austria rose from less than 400 in 2000 to over 1,200 in 2006, and dropped to about 1,000 in 2010. These figures do not include those enrolled in private universities and music students who study in state and private conservatoriums. Another data source records altogether 1,400 Chinese students in Austria in 2009 (Eurostat 2011). In contrast to some other groups of Chinese migrants, these young students usually come independently from big cities such as Běijīng, Shànghăi, Hángzhoū 杭州 and Chéngdū 成都, with no prior network of migration and no extended kinship connection. As an urban educated sub-community speaking pǔtōnghuà 普通话, ${ }^{19}$ these students have an ambivalent role in the Chinese immigrant economy. While on the one hand they serve as cheap labour for the Chinese catering business, like their Dōngběi and Fújiàn co-ethnics, on the other hand they offer high-end skills and knowledge such as computer programming or composition in standard Chinese in

19 The term indicating standard Chinese in mainland China. 
the local Chinese newspapers, competencies that other groups in the Chinese community cannot replace. Their cultivation of a cosmopolitan way of life, including eating out, to a certain extent has provided the Chinese immigrant economy with new stimuli.

Austria has had relatively stringent migration policies in regard to work permits and residence permits for foreign students. The immigration of highly skilled labour has also been controlled tightly, not only through high thresholds, but also through complicated administrative requirements (Kwok 2009). This may explain the limited number of skilled Chinese migrants coming to Austria as well as of Chinese students who stay on in Austria after their graduation. The coming into force of the new Aliens Law Reform Act in 2011 (Änderung des Niederlassungs- und Aufenthaltsgesetzes 2011) and the introduction of the red-white-red card ${ }^{20}$ signal a certain degree of relaxation of control and open up more channels for skilled migrants. Whether these new regulations can help to absorb more Chinese graduates and Chinese skilled labour remains to be seen.

The predecessors of these young students are a group of better-educated urban Chinese who arrived in the 1980s and 1990s. Some left China in the aftermath of the 1989 Tiānānmén 天安门 crackdown. Most of these people have achieved a comparably stable life and established careers in various occupational areas in Austria. Among them are professionals who work in the mainstream economy (e.g., technician and software experts for the Siemens company); others endeavour to continue practicing their acquired professional knowledge and skills as artists, martial arts masters and doctors in traditional Chinese medicine (Springer 2004; Steiger 2008). Some venture into different branches of the Chinese immigrant economy, such as trading and tourism. What is worth noting is that the flourishing Chinese tourism in Austria was pioneered by a couple of Chinese migrants originating from Běijīng and Shànghăi, who possessed widespread and solid social networks in China. ${ }^{21}$

All in all, while Austria was far from a popular destination for non-qiáoxiāng Chinese migrants in the early reform era, it has became a common transit channel for various Chinese migration flows because of its strategic location. Chinese students who aimed at going to Britain and France saw Austria as a gateway to enter Western Europe when it was still relatively easy to obtain a student visa in the early 1990s. Small-scale entrepreneurs who tried their luck in Hungary during the 'Hun-

20 The red-white-red card has been introduced to replace the 'key personnel' system in order to enhance Austrian economic competitiveness. Instead of being restricted by fixed yearly quotas for new working immigrants, the red-white-red card is guided by a points model based on criteria, and is without quota limitations. Besides highly skilled persons, it also opens channels for university graduates who study in Austria as well as skilled labour.

21 Information obtained from first-hand interviews. See Kwok (2012), chapters 7-9 and appendix I. 
gary fever, ${ }^{22}$ but failed crossed over the border to look for a more regulated business environment in Austria. Taiwanese business people in the computer branch who aimed to explore Eastern Europe or Western Europe built up their bases in Austria before expanding their commercial activities further. Clandestine Zhèjiāngnese who planned to count on their relatives in Spain or in France were stuck in Austria because they had no more money to pay for the rest of the journey. Fújiànese who left Eastern Europe and obtained a residence permit in Italy - thanks to several amnesty programmes - came to work in Austria because of higher wages. With the years, those people who first came for a stopover have gradually settled down in Austria and established their families and networks. If these Chinese migrants at first took Austria as a transit country because of its geographical position, their later settlement can be attributed to Austrian migration policies and institutional welfare arrangements as well as the opportunities offered by the Chinese immigrant economy. ${ }^{23}$ Moreover, in the context of 'new Chinese migration order', many Chinese migrants, particularly students and irregular migrants have arrived in Austria for opportunities since the new millennium. In the course of time, Austria has evolved from a common transit corridor to a settlement country for Chinese migrants, although its role as a temporary stopover has not been lost.

\section{Conclusion}

As shown in this text, Chinese migration to Austria since the 1980s does not present a picture of homogenous migratory trajectories and stories. With various migration flows and patterns intersecting each other, a Chinese community marked by diversity, in terms of both migration background and socio-economic profile, has gradually taken shape in Austria. Precisely because of this diversity, social stratification within the Chinese community has gradually emerged. Zhèjiāng Chinese originating from the qiáoxiāng areas have formed the first and largest subgroup of Chinese since the 1980s. Most of them enjoy sufficient support networks and stable economic conditions. Usually they run their own small- or middle-sized business, if they are not regular wage-earners. The Taiwanese and the educated mainland Chinese who migrated to Austria earlier have been able to promote themselves in vari-

22 Between October 1988 and April 1992, Chinese nationals were allowed to enter Hungary without a visa. Around 45,000 Chinese are estimated to have passed through Hungary to migrate further to other European countries as well as to North America. Suddenly Hungary was full not only of Chinese, but also of Chinese cheap consumer products. After the termination of visa-free entry in 1992, the number of Chinese fell to less than 20,000. This period has been described as that of 'Hungary fever'. For details see Pieke (2002) and Nyiri (1999).

23 Migration policies, welfare arrangements and the Chinese immigrant economy interact to exert both positive and negative effects on the Chinese community. Detailed analyses of these factors are provided in Kwok (2012), but they are beyond the scope of this paper. 
ous professional fields. They have also established certain social and economic bases, and some have even accumulated wealth and a reputation through their active involvement in the burgeoning Chinese tourism and cultural industry. In contrast, late-comers such as the irregular migrants from Fújiàn and Dōngběi are still struggling at the bottom of the Chinese community. Although they are perceived as new blood for the Chinese immigrant economy, offering cheap and convenient labour, many of them are exploited and stuck in a difficult predicament. The young Chinese students have an ambivalent but flexible status. While they also work in the Chinese informal economy, the fact of being a student promises them a chance of upward mobility.

In addition, this paper has illustrated how Austria performed different rolesactive or passive - in various historical periods within the context of Chinese migration to Europe. During the first wave of Zhèjiāng migration to Europe at the turn of the 20th century, Austria shared a role with other European countries in receiving Qingtián migrants. Amid large-scale Chinese migration from a politically unstable Asia to Europe in the post-World War II period, Austria merely quietly absorbed a tiny number of Taiwanese and ethnic Chinese from Indochina. In the initial stage of the Chinese reform era, Austria was not a popular choice for most Chinese migrants. Besides qiáoxiāng Chinese, what Austria received were largely the spillover migrants from other European destination countries on a relatively small scale. By the end of the 20th century, the Chinese migration landscape in Austria had been shifted enormously by the intersection of two historical factors: firstly, the open-door policy of the PRC, and secondly, the end of the Cold War. The first phenomenon, mingled with other factors such as globalisation, has shaped what Pieke (2007) defines as the 'new Chinese migration order'. This new order has profoundly influenced Chinese migration movements in nearly all corners of the world, including Austria. The second factor has had long-lasting effects for Austria and its neighbouring countries in particular. With the abolition of political borders between the Western and the Eastern blocs, Austria became a popular corridor or stopover for flows of Chinese migrants between Eastern and Western Europe, as well as between the old and new destinations. Throughout the last 30 years, while spillover and stopover have been going on in various degrees, many of the former temporary migrants have made Austria their home for settlement and gradually a destination of migration for their relatives and friends. 


\section{REFERENCES}

Benton, Gregor, and Edmund T. Gomez. The Chinese in Britain, 1800-Present: Economy, Transnationalism, Identity. Basingstoke: Palgrave Macmillan, 2008

Benton, Gregor, and Frank Pieke, eds. The Chinese in Europe. Basingstoke: Macmillan, 1998

Bundesministerium für Inneres. Asylwesen Jahrestatistiken 1999-2010, http://www.bmi.gv.at/cms/BMI_Asylwesen/statistik/start.aspx, accessed October 2011

Christiansen, Flemming. Chinatown, Europe: An Exploration of Overseas Chinese Identity in the 1990s. London and New York: Routledge Curzon, 2003

Cologna, Daniele. "Chinese Immigrant Entrepreneurs in Italy: Strengths and Weaknesses of an Ethnic Enclave Economy." In Asian Migrants and European Labour Markets: Patterns and Processes of Immigrant Labour Market Insertion in Europe, edited by Ernst Spaan, Felicitas Hillmann and Ton van Naerssen. London and New York: Rouledge, 2005, pp. 262-284

Eurostat. "Foreign Students by Level of Education and Country of Origin", http://epp.eurostat.ec.europa.eu/portal/page/portal/education/data/database, accessed November 2011

Eurostat. "Population by Sex, Age Group and Citizenship", http://appsso.eurostat.ec.europa.eu/nui/submitViewTableAction.do, accessed November 2012

Gebesmair, Andreas, ed. Randzonen der Kreativwirtschaft. Türkische, chinesische und südasiatische Kulturunternehmungen in Wien. Wien: Lit Verlag, 2009

Hausner, Katharina Elisabeth. "Integration durch Selbstständigkeit. ChinesInnen und TaiwanesInnen im Ethnic Business.” M.A. thesis, University of Vienna, 2009

Hintermann, Christine, and Ursula Reeger. "On Nurses and News Vendors: Asian Immigrants on the Vienna Labour Market." In Asian Migrants and European Labour Markets: Patterns and Processes of Immigrant Labour Market Insertion in Europe, edited by Ernst Spaan, Felicitas Hillmann and Ton van Naerssen. London and New York: Routledge, 2005, pp. 56-79

John, Michael, and Albert Lichtblau. "Die Chinesen." In Schmelztiegel Wien, einst und jetzt, zur Geschichte und Gegenwart von Zuwanderung und Minderheiten. Wien: Böhlau, 1990

Kaminski, Gerd, and Else Unterrieder. Von Österreichern und Chinesen. Wien: Europa Verlag, 1980

Khan-Svik, Gabriele. "Chinese Schools in Austria: A Pilot Study.” In China's Traditions: Wings or Shackles for China's Modernisation?, edited by Gerd Kaminski. Vienna: ÖGCF, 2003, pp. 163-173

Kreiss1, Barbara. "Merkmale der chinesischen Migration nach Österreich.” In China Report, 131132, 1999, pp. 60-79

Kwok, Kim. "Rechtliche Rahmenbedingungen migrantischer Kulturarbeit in Österreich.” In Randzonen der Kreativwirtschaft. Türkische, chinesische und südasiatische Kulturunternehmungen in Wien, edited by Andreas Gebesmair. Wien: Lit Verlag, 2009, pp. $123-138$

Kwok, Kim. "Chinese Immigrant Economy in Vienna in Transnational Era." PhD thesis, University of Vienna, 2012

Larin, Alexander G. "Chinese in Russia: An Historical Perspective." In The Chinese in Europe, edited by Gregor Benton and Frank Pieke. Basingstoke: Macmillan, 1998, pp. 281-300

Leung, Maggi W. H. Chinese Migration in Germany. Making Home in Transnational Space. Frankfurt am Main: Verlag für Interkulturelle Kommunikation, 2004

Li, Minghuan. The Chinese Community in Europe. Amsterdam: EFCO, 1999a 
Lǐ, Mínghuān 李明欢. “Zhànqián zhōngguórén yímín xīōu lìshí kăchá” 战前中国人移民西欧历 史考察 [Historical Investigation of Chinese Migration in Europe before the First World War]. In Huáqiáo huárén lìshí yánjiū 华侨华人历史研究 [Overseas Chinese History Studies], 3,1999b, pp. 16-25

Lǔ, Mínghuān 李明欢. Ōuzhoū huáqiáo huárén shí 欧洲华侨华人史 [History of Overseas Chinese in Europe]. Běiijīng: Zhōngguó huáqiáo chūbănshè, 2002

Lǐ, Mínghuān 李明欢. “Ōuzhoū huárén shèhuì pōuxī: rénkoǔ, jīngjì, dìwèi yǔ fēnhuà” 欧洲华人 社会剖析: 人口、经济、地位与分化 [Social Analyses of Chinese in Europe: Demography, Economy, Status and Differences]. In Shìiè Mínzú 世界民族 [World Ethno-National Studies], 5, 2009, pp 47-53

Lǐ, Mínghuān 李明欢, Jiāng Hóngzhēng 江宏真, and Yú Yùnpíng 俞运平. “Yīgè lǔ̄ou xīn qiāoxiāng dē xíngchēng, yíngxiăng, wèntí yǔ duìcè - Fújìanshěn Sānmíngshìi Míngxīxiàn xīn qiáoxiāng diàoyán bàogào"一个旅欧新侨乡的形成、影响、问题与对策 一福建省三明市 明溪县新侨乡调研报告 [Formation, Influences, Problems and Solutions of a New Qiáoxiāng with People Sojourning in Europe - Study Report on New Sojourner's Home Town in Míngxī, Sānmíng in Fújìn]. In Huáqiáo huárén lìshi yánjiū 华侨华人历史研究 [Overseas Chinese History Studies], 4, 2003, pp. 8-15

Lǐ, Yáng 李阳. “Lüào huárén shǐ màntán (1)” 旅奥华人史漫谈 1 [Talking About the History of Chinese Sojourners in Austria 1]. In Àohuá 奥华 [Austria-China], 1, 1991a, pp 8-9

Lŭ, Yáng 李阳. “Lüào huárén shǐ màntán (2)” 旅奥华人史漫谈 2 [Talking About the History of Chinese Sojourners in Austria 2]. In Àohuá 奥华 [Austria-China], 2, 1991b, pp 4-5

Lǐ, Yáng 李阳. “Lüào huárén shǐ màntán (3)” 旅奥华人史漫谈 3 [Talking About the History of Chinese Sojourners in Austria 3]. In Àohuá 奥华 [Austria-China], 3, 1992a, pp 5-6

Lǐ, Yáng 李阳. “Lüào huárén shǐ màntán (4)” 旅奥华人史漫谈 4 [Talking About the History of Chinese Sojourners in Austria 4]. In Àohuá㇒奥华 [Austria-China], 4, 1992b, pp 9-10

Mosleh, Fariba. "Wien - Chinatown (In-)Visible. Eine stadtethnologische Bestandsaufnahme zur Verortung der Chinesischen Community in Wien." M.A. thesis, University of Vienna, 2012

Nagy, Dorottya. Migration and Theology: The Case of Chinese Christian Communities in Hungary and Romania in the Globalisation Context. Zoetermeer: Boek Encentrum, 2009

Nyíri, Pál. New Chinese Migrants in Europe: The Case of the Chinese Community in Hungary. Aldershot: Ashgate, 1999

Paul, Marc. "The Dongbei: The New Chinese Immigrant in Paris." In Globalising Chinese Migration, edited by Pál Nyíri and Igor Saveliev. Aldershot: Ashgate, 2002, pp. 120-128

Pieke, Frank. Recent Trends in Chinese Migration to Europe: Fujianese Migration in Perspective. Geneva: International Organisation for Migration, 2002

Pieke, Frank. "Editorial Introduction: Community and Identity in the New Chinese Migration Order." Population, Space and Place, 13, 2007, pp. 81-94

Pieke, Frank, Pál Nyíri, Mette Thunø, and Antonella Ceccagno. Transnational Chinese: Fujianese Migrants in Europe. Stanford CA: Stanford University Press, 2004

Schäfer, Carsten. "Auslandschinesen in Österreich - Identität und Identitätskonstruktion zwischen Heimat und Fremde unter besonderer Berücksichtigung der Ouzhou Lianhezhoubao Aodili." M.A. thesis, University of Vienna, 2009

Sòng, Quánchéng 宋全成. “Ōuzhoū de zhōngguó xínyimín: guímó jí tèzhēn de shèhuì fēnx 的中国新移民: 规模及特征的社会分析 [Chinese New Migrants in Europe: Social Analyses of Scale and Features]. In Shāndōng dàxué xuébào zhéxué shèhuikēxué băn 山东大学学报哲 学社会科学版 [Journal of Shāndōng University, Philosophy and Social Sciences], 2, 2011, pp. $144-150$ 
Springer, Lena. "Professionelle und kulturelle Positionierungen von Ärzten für chinesische Medizin aus der VR China in Wien." M.A. thesis, University of Vienna, 2004

Stadt Wien. Statistisches Jahrbuch der Stadt Wien. Wien, 2012

Stanek, Eduard. Verfolgt, Verjagt, Vertrieben: Flüchtlinge in Österreich, von 1945-1984. Wien: Europa Verlag, 1985

Statistik Austria. Statistisches Jahrbuch Österreich 2002, 2005, 2012, http://www.statistik.at, accessed May 2006 and March 2013

Statistik Austria. Volkszählung 2001, http:// www.statistik.at, accessed May 2006

Statistisches Zentralamt. Ergebnisse der Volkszählung 1961. Wien, 1964

Statistisches Zentralamt. Ergebnisse der Volkszählung 1971. Wien, 1974

Statistisches Zentralamt. Volkszählung 1981. Hauptergebnisse I Österreich. Wien, 1984

Statistisches Zentralamt. Volkszählung 1991. Hauptergebnisse II Österreich. Wien, 1994

Steiger, Katharina. "Migration und Identität. Chinesische Künstler in Wien.” M.A. thesis, University of Vienna, 2008

Summerskill, Michael. China on the Western Front: Britain's Chinese Work Force in the First World War. London: Michael Summerskill, 1982

Thunø, Mette. "Moving Stones from China to Europe: The Dynamics of Emigration from Zhejiang to Europe.” In Internal and International Migration, Chinese Perspectives, edited by Frank Pieke and Hein Mallee. Richmond: Curzon, 1999, pp. 159-180

Vuong, Martina. "Die Migration der ethnischen Chinesen (Hoa) von Nord-Vietnam nach Österreich. Push- und Pull-Faktoren für die Massenflucht von 1978 und 1979 im historischen, innen- und außenpolitischen Kontext.” M.A. thesis, University of Vienna, 2007

Waldrauch, Harald, and Karin Sohler. Migrationorganisationen in der Großstadt. Entstehung, Strukturen und Aktivitäten am Beispiel Wiens. Frankfurt and New York: Campus, 2004

Wang, Kuo-Chiang. "Second Generation Chinese Immigrant Entrepreneurship in Vienna: Identities and Economic Activities." M.A. thesis, University of Vienna, 2008

Xiăo, Dì 晓地.“Yìxiāng sìshí nián, jì Xú Zhīxiù jiàoshoù” 异乡四十年. 记徐芝秀教授 [Forty Years on Foreign Soil. On Professor Xu Zhixiu] In Ōuhuá 欧华 [Europe-China], 5, 1995, pp. 20-22

Xiang, Biao. "The Making of Mobile Subjects: How Institution Reform and Outmigration Intersect in Northeast China." In Development, 50/4, 2007, pp. 69-74

Xiang, Biao, and Wei Shen. "International Student Migration and Social Stratification in China." Centre on Migration, Policy and Society Working Paper No. 70, 2009

Yú, Shūpíng 俞叔平. “Liúxué shídài de huíyi” 留学时代的回忆 [Memories From the Time of Studying Overseas]. In Ōuhuá 欧华 [Europe-China], 1, 1993, pp. 20-21

Zhuāng, Guótǔ 庄国土. “Shìjìe huáqiáo huárén shùliàng hé fēnbù de lìshǐbiànhuà”世界华侨华人 数量和分布的历史变化 [Historical Changes in Numbers and Distribution of Overseas Chinese in the World]. In Shijie Lish ̌ 世界历史 [World History], 5, 2011, pp. 4-14 


\section{GLOSSARY}

\begin{tabular}{|c|c|}
\hline Běijīng & 北京 \\
\hline Chēn Yuánfēng & 陈元丰 \\
\hline Chéngdū & 成都 \\
\hline Dōngběi & 东北 \\
\hline Fújiàn & 福建 \\
\hline Fúqīng & 福清 \\
\hline Fúzhoū & 福州 \\
\hline Guăngdōng & 广东 \\
\hline Guómíndăng & 国民党 \\
\hline Hángzhoū & 杭州 \\
\hline Hēilóngjiāng & 黑龙江, \\
\hline Jílín & 吉林 \\
\hline Liáoníng & 辽宁 \\
\hline Lìshuǐ & 丽水 \\
\hline Májiàng & 麻将 \\
\hline pǔtōnghuà & 普通话 \\
\hline Qí Jǐngshān & 齐景山 \\
\hline qiáoxiāng & 侨乡 \\
\hline Qīngdăo & 青岛 \\
\hline Qīngtián & 青田 \\
\hline qīngtiánshí & 青田石 \\
\hline Sānmíng & 三明 \\
\hline Shāndōng & 山东 \\
\hline Shànghăi & 上海 \\
\hline Tiānānmén & 天安门 \\
\hline Wénchéng & 文成 \\
\hline Wēnzhōu & 温州 \\
\hline Wú Jiācái & 吴家财 \\
\hline Xiānggăng & 香港 \\
\hline Xú Zhīxiù & 徐芝秀 \\
\hline
\end{tabular}

Yú Shūpíng 俞叔平

Zhèjiāng

\section{浙江}

capital city of the People's Republic of China

believed to be the pioneer who went to Europe from

Zhèjiāng in a steamer in the late 19th century

capital city of Sìchuān province

Northeastern China

southern coastal province in China

city in Fújiàn province

capital city of Fújiàn province

southern coastal province in China

dominant political party of the Republic of China

from 1912 onwards; ruling party of modern Taiwan

capital city of Zhèjiāng province

northeastern province in China

northeastern province in China

northeastern province in China

city in Zhèjiāng province

Chinese game played by four players

Standard Chinese commonly spoken in the People's Republic of China.

pioneer Chinese restaurant owner in Vienna of

Shāndōngnese origin and Taiwanese background

home town of overseas Chinese

city in Shāndōng province

city in Zhèjiāng province

special pale-green soapstone from the region of Qīngtián suitable for stone carving

city in Fújiàn province

northern province in China

city in China

Gate of Heavenly Peace, a famous monument in

Bĕijīng

city in Zhèjiāng province

city in Zhèjiāng province

pioneer Chinese restaurant owner in Vienna of

Shāndōngese origin and Taiwanese background

Hong Kong; a former British colony, returned to the

People's Republic of China in 1997

Chinese who came from Shànghăi to Vienna in the early 1950s; later she became a lecturer in Chinese language at the University of Vienna. She died in the 2000s in Vienna.

Zhèjiāngnese student who studied in Vienna in the 1930s; later he became a diplomat for the Republic of China and died in 1971 in Taiwan.

coastal province in China 